\title{
腹腔鏡補助下腟式子宮全摘術後に子宮体癌と診断された一例
}

小樽協会病院産婦人科

山中郁仁、内山響子、太枝美帆、恐神博行、山中 雅、郷久晴朗

\section{A Case of Endometrial Cancer Detected By Laparoscopically-Assisted Vaginal Hysterectomy}

\author{
Ikuhito Yamanaka, Kyoko Uchiyama, Miho Oeda, \\ Hiroyuki Osogami, Miyabi Yamanaka, Seiro Satohisa \\ Department of Obsterics and Gynecology, Otarukyokai hospital
}

\begin{abstract}
Laparoscopic surgery is increasingly recommended for the treatment of benign uterine pathologies. We report a case of endometrial cancer diagnosed after laparoscopically-assisted vaginal hysterectomy for uterine fibroids. The patient was 70 years-of-age, gravida 2, para 2. She was referred to our department for evaluation of a pelvic mass. Magnetic resonance imaging revealed numerous intramural leiomyomas ranging from 1 to $9 \mathrm{~cm}$. Pap smears of endometrial scrapings showed no atypical cells. She was diagnosed with uterine fibroids preoperatively, and underwent laparoscopically-assisted vaginal hysterectomy and bilateral salpingo-oophorectomy. The pathologic findings revealed serous adenocarcinoma of the uterine corpus without deep myometrial invasion. She received six courses of adjuvant chemotherapy with paclitaxel and carboplatin. There was no evidence of recurrent and metastatic tumor one year after the laparoscopic intervention. As use of laparoscopic hysterectomy increases, we need to be aware of the possibility of adenocarcinoma in elderly women with multiple leiomyomas, even when endometrial cytology is negative.
\end{abstract}

Key Words: laparoscope, endometrial cancer, endometrial cytology

\section{緒言}

現在、子宮を摘出する方法としては腹式子宮全 摘術、腟式子宮全摘術、さらに腹腔鏡を用いた子 宮全摘術が行われている。しかし、子宮体部の悪 性疾患に対しては子宮摘出だけではなくリンパ節 郭清や腹水採取等を含めた手術が必要となるため、 術前に細胞診や画像診断などによる検査を実施し 悪性の可能性を否定しておくことが重要である。 また現段階においては、悪性子宮疾患に対する腹 腔鏡下手術は保険診療上認められておらず、一部 の施設を除き腹腔鏡を用いた子宮全摘術は良性子 宮疾患に対してのみ施行されている。今回我々は 術前検査では悪性所見を認めず、腹腔鏡補助下腟 式子宮全摘術後に摘出標本にて初めて子宮体癌と 診断された症例を経験したので報告する。

\section{症例}

患者：70歳

妊娠・分婏歴： 2 経妊 2 経産。

既往歴：高血圧、糖尿病、高脂血症

現病歴：下腹痛を主訴に近医内科を受診し骨盤内 腫瘍を指摘され当科を紹介受診した。内診所見は 可動性良好な臍下部に達する子宮を触知し、経臸 超音波検查では子宮体部に大小の低エコー腫瘤を 認めた。子宮澒部細胞診はべセスダ分類でNILM、 日母分類でclass Iであった。子宮内膜細胞診（内 膜ブラシにて採取）は出血性背景もなく N/C比や 核の異常または細胞重積なども認めず陰性と判定 された。血液検査では炎症反応などの異常を認め なかった。

骨盤MRI画像所見：T2強調像で子宮体部前壁、 
後壁、底部の筋層内に最大約 9 センチの辺縁明瞭 な低信号腫瘤を認め子宮筋腫が考えられた。その 中で一部高信号を示す結節を認めたが出血・壊 死・周囲への浸潤像を認めないためcellular leiomyomaを考えていた（図1 A、1B）。

\section{図 1 A 骨盤造影 MRIT 2強調矢状断像}

子宮体部前壁, 後壁, 底部の筋層内に最大約 9 センチの境 界明瞭な結節を認め子宮筋腫と診断。高信号を示す結節 （矢印）は出血・壊死・周囲への浸潤像もないためcellular leiomyomaと考えていた。

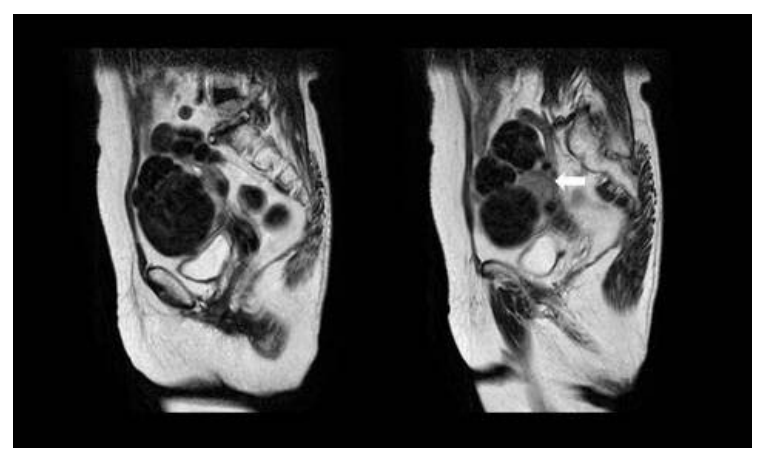

図 1 B 骨盤造影MRIT2強調横断像

子宮内膜の後方に高信号を示す結節（矢印）を認めた。

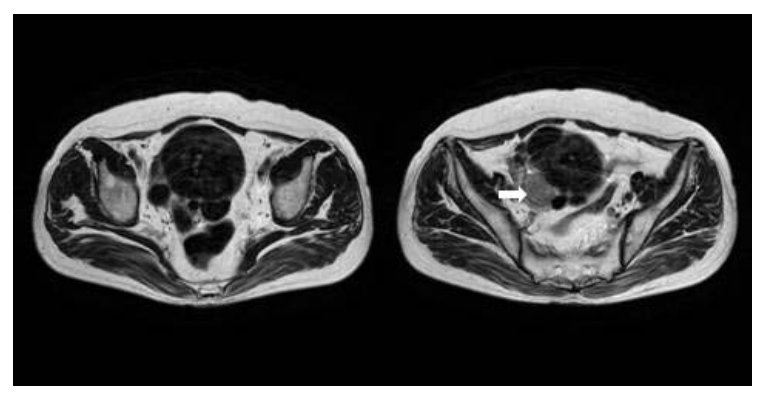

手術所見：全身麻酔下に気腹法にて腹腔鏡下手術 を施行した。スコープで穿刺している層を視認し ながら腹腔内に入る、オプティカル法で臍部に $5 \mathrm{~mm}$ トロカールを挿入し、左右下腹部に $5 \mathrm{~mm}$ 卜 ロカールを挿入した。腹腔内に腹水や瘉着所見は なく、大網や腹膜に異常所見を認めなかった。子 宮に複数の筋腫を認めるものの漿膜は平滑であり、 両側付属器に異常を認めなかった。腹腔鏡操作で はLigaSureを用いて子宮上部勒带及び左右付属器 を凝固・切断し、膀胱子宮窩腹膜をモノポーラー で剥離・切断した。腟式操作で基勒带及び子宮動 脈を結紮・切断し、子宮を折半・分割して子宮を 搬出した。最後に腹腔鏡下にて止血を確認し腹腔 内を洗浄して腹腔鏡補助下胵式子宮全摘術及び両 側付属器摘出術を終了した。

摘出標本 : 摘出子宮及び両側付属器の重量は $450 \mathrm{~g}$ であった。MRIで高信号を示した結節は子宮内膜 全周性に発生した内向発育型の腫瘍であった（図 $2 \mathrm{~A} 、 2 \mathrm{~B})$ 。
図 $2 \mathrm{~A}$ 摘出標本

写真左の黒線の部分を切ったものが図 $2 \mathrm{~B}$ 。

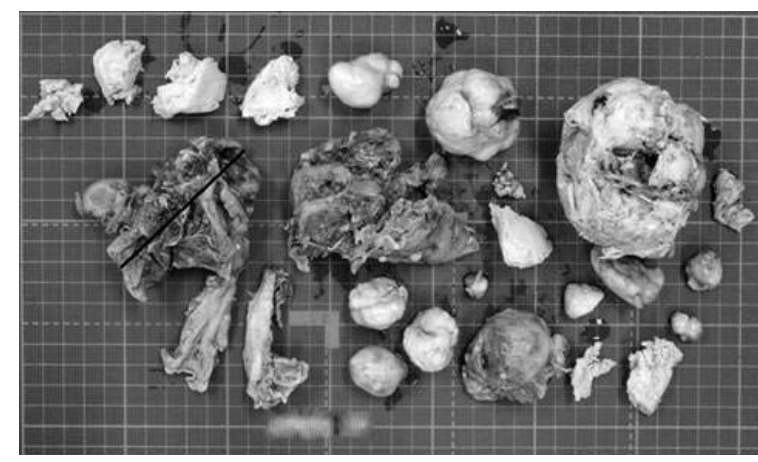

目2B 摘出標本

子宮内膜に対して内向きに限局した発育をしめす腫瘍（矢 印）を認めた。左側が子宮内膜面で右側が子宮漿膜面であ る。*は子宮筋腫

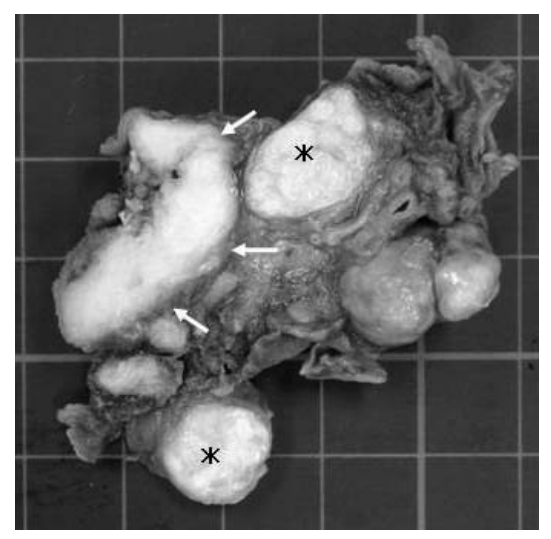

病理所見：弱拡大像で間質の豊かな茥に核小体の 明瞭な異型性の強い腫瘍細胞が付着し増殖する所 見を認めた（図 $3 \mathrm{~A}$ )。また強拡大像でN/C比の増 大した異型細胞が内部の血管や豊富な間質を伴う 線維性間質の茥に付着するように増殖している所 見を認めた (図 $3 \mathrm{~B}$ )。免疫組織化学的に異型細胞 はp53が一部陽性でERは陰性であった。以上から 子宮体部内膜に全周性に発生した（限局型・内向 型） serous adenocarcinomaと診断された。 Carcinomaの浸潤の深さは約 $10 \mathrm{~mm}$ で子宮外面か らは約 $12 \mathrm{~mm}$ であり進行期はpT1bNxであった。 術後経過：正確な進行期決定のためにはリンパ節 郭清が必要であることを説明したが、患者は追加 手術を希望しなかった。本症例は仮にリンパ節転 移がなかったとしても、子宮体癌治療ガイドライ ンに記載されている術後再発リスク分類で、中リ スク群に分類され化学療法または放射線療法がの ぞましいとされている。そのため術後化学療法 （TC療法）を 6 コース施行した。現在、術後 1 年 経過したが再発兆候を認めず、今後は長期的に慎 重に管理していく予定である。 
図 $3 A$ 病理組織像（HE染色×100倍） 間質の豊かな茎に核小体の明瞭な異型性の強い腫瘍 細胞が付着し増殖する所見を認める。

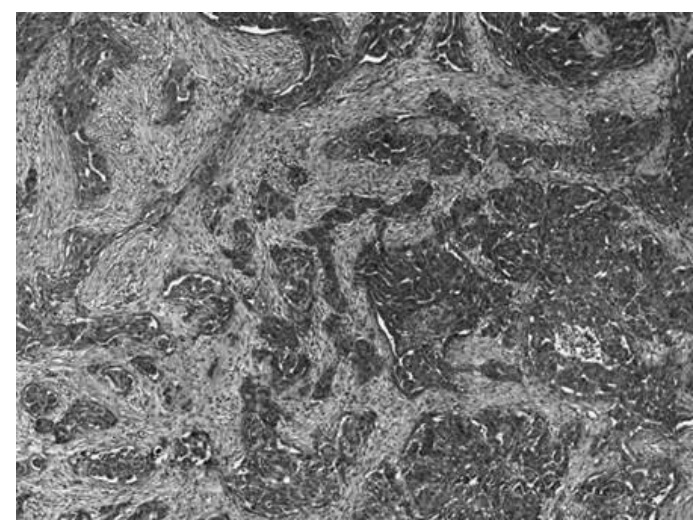

図 $3 B$ 病理組織像 (HE染色X400倍) N/C比の増大した異型細胞が内部の血管や豊富な間 質を伴う繊維性間質の茎に付着するように増殖。

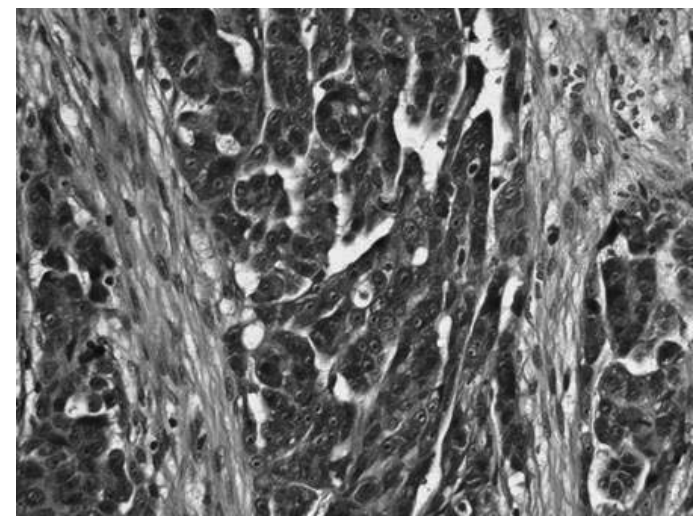

考察

近年、我が国において子宮体癌は増加の一途を 逆っているが、早期発見されると予後はよいため 子宮体癌を早期に診断することが重要であること は言うまでもない。しかし、早期の子宮体癌は画 像や腫瘍マーカーに異常を認めないことが多く、 早期発見のためには内膜細胞診や組織診の果たす 役割が重要である ${ }^{1)}$ 。子宮体癌取扱い規約による と内膜細胞診による子宮体癌の検出率は 90 ～95\% に及ぶとされている2)。しかし、この值をそのま ま精度とするには問題があるとされており、初回 施行時の検出率は約 $80 \%$ とされている ${ }^{3)}$ 。内膜細 胞診が偽陰性となる因子として腫瘍サイズ、臨床 進行期、分化度、腫瘍占拠部位が考えられている ${ }^{3)}$ 。 類内膜腺癌以外の組織型では偽陰性症例がなかっ たが、細胞異型のそしい類内膜腺癌は偽陰性を生 じやすいとされ、組織型も偽陰性の因子としてあ げられている ${ }^{4)}$ 。さらに子宮筋腫が合併している と偽陰性率が高くなる ${ }^{5)}$ といわれ子宮内腔を占拠
する病変が存在する場合には内膜細胞の採取が困 難となることもあり慎重に診断すべきだとされて (るる ${ }^{6)}$ 。そのため、内膜細胞診が陰性であっても、 閉経後の出血を繰り返したり、高リスク症例では 経腟超音波検查、MRI、子宮鏡による内膜組織診 を併用することを针める報告もある7

今回の症例では明らかな不正出血を認めないた め主訴が非典型的であった。内膜細胞診では内膜 細胞が採取されていたものの細胞診陽性と判断す る細胞は認められなかった。この理由として子宮 内腔を占拠する筋腫のため、十分な内膜細胞の採 取が困難であったと考えられる。細胞診以外の検 查では、経腟超音波検查において明らかな内膜肥 厚を認めず、MRIでも子宮体癌を疑わせるような 所見も認めなかったため、子宮体癌の術前診断は 難しいものとなった。今後、確実な術前診断をす るためには必要に応じて、子宮鏡による組織検査 や子宮内膜の全面掻把による組織診断を実施すべ きかもしれない。

早期子宮体癌に対する腹腔鏡下手術は諸外国か ら多数の報告があり、我が国においても多くの施 設で導入され、症例も集積し、様々な臨床デー夕 が報告されている。しかし、それらの報告は術前 に子宮体癌と診断され腹腔鏡下手術が施行された 報告であり、腹腔鏡下手術が実施された後に子宮 体癌と診断された症例は筆者の知る限り国内での 文献報告はない。

海外において早期子宮体癌症例であれば、腹腔 鏡下手術と開腹手術に再発率や予後に差はないと 報告されていて ${ }^{8)}$ 、国内でも腹腔鏡下子宮体癌手 術に関する論文がいまだ少ないものの開腹手術に 匹敵する治療成績であったと報告されている ${ }^{9,10)}$ 。 しかしながら腹腔鏡補助下腟式子宮全摘術におい て、腹腔内細胞診陽性率が高くなるという意見や 腟断端やトロッカー穿刺部の再発が報告されてい て、現時点では開腹手術に代わって腹腔鏡下手術 が標準術式として推奨できるデー夕はないとされ ている ${ }^{11)}$ 。また子宮体癌を念頭においた腹腔鏡下 手術では、手術前に外子宮口の縫合閉鎖やウテリ ンマニピュレーターを使用しないなどして腫瘍細 胞の漏出を防ぐ工夫的) が実施されている。今回の 手術では、子宮体癌を念頭に抒いていなかったた めに、それらの処置を実施しなかった。しかし今 後、今回のような症例に対しては、子宮体癌の術 前診断がついていなくても外子宮口の縫合閉鎖な どの処置を併用し、腹腔鏡下手術を実施するのが 望ましいかもしれない。 
日本産科婦人科内視鏡学会のアンケート調查に よれば、子宮全摘出は2006年に施行された1531例 のうち28.5\%がLHかTLHであり、2007年では2502 例のうち $50.1 \%$ \%LHかTLHであったと報告されて いる。そのため今後もLHとTLHによる子宮全摘 出は、増加していくと考えられる。子宮が大きい 場合には、腹腔内での子宮筋腫核出や子宮を折半 して子宮径を縮小したり、モルセレーターである 程度回収してから経腟的に子宮を回収することは、 実際によく行われている手技である。しかし、開 腹あるいは腹腔鏡下による筋腫核出術後に医原的 なdisseminated peritoneal leiomyomatosisが発症し たという報告もある ${ }^{12)}$ 。それらを防ぐためには、 腹腔内に散布した子宮あるいは筋腫組織の除去が 必要である ${ }^{13)}$ とされているが、万が一子宮内に癌 組織が混在していた場合は、より丹念な組織除去 が必要とされるであろう。

今回我々は術前に子宮体癌と診断できず腹腔鏡 下手術後に子宮体癌と診断した症例を経験した。 今後は腹腔鏡下手術による子宮全摘出の症例が増 加することは間違いなく、将来的に子宮体癌の腹 腔鏡下手術が保険収載され標準術式となるかもし れない。しかし、重要なことは術前に子宮体癌と 診断することである。今回のように閉経後の症例 で、特異的な主訴もなく子宮䅡部・内膜細胞診に 異常がなかったとしても、子宮内腔を占拠したり 多発する筋腫を認めた場合には特に慎重な診断が 必要とされると考えられた。

\section{参考文献}

1 ）荷見勝彦、杉山裕子：子宮体癌検診の現況と早期発見 の見地よりみた問題点、産婦人科治療、2000；81：8084.

2 ) 日本産科婦人科学会、日本病理学会、日本医学放射線 学会編：子宮体癌取扱い規約（改定第 2 版）、1996： 18、金原出版 (東京).

3 ）大和田倫孝：子宮体癌の診断一内膜細胞診偽陰性例の 存在と異型ポリープ状腺筋腫との鑑別診断、産婦の実 際、 $2008 ； 57 ： 1688-1694$.

4 ）上坊敏子、他：子宮内膜細胞診診断精度の検討、日臨 細胞会誌、2000；39：381-388.

5 ）加藤久盛、他：子宮内膜細胞診が陰性評価であった子 宮体癌の再検討、日産婦誌、 $2007 ； 59 ： 425$ (抄録).

6 ）森本恵爾、他：術前に診断し得なかった子宮体癌症例 の検討、日産婦東京会誌、 $2009 ; 58 ： 251-255$.

7 ) 大和田倫孝、他：閉経後出血患者における子宮体癌の 看過なき診断法、産婦の世界、2007； $59 ： 405-469$.
8 ) Malzoni MT, et al: Total laparoscopic hysterectomy versus abdominal hysterectomy with lymphadnectomy for early-stage endometrial cancer: a prospective randomized study. Gynecol Oncol 2009; 112: 126-133.

9 ) 舟本寛、他：当科における子宮体癌に対する腹腔鏡下 手術の検討、日本婦人科腫瘍学会雑誌、2009；27： 511-517.

10）光部兼六郎、他：当科における子宮体癌に対する腹腔 鏡下手術、日本産婦人科内視鏡学会雑誌、2010；26： 281-287.

11）日本婦人科腫瘍学会編：子宮体癌治療ガイドライン 2009年版、2009：67、金原出版 (東京).

12) Paul PG, Koshy AK.: Multiple peritoneal parasitic myomas after laparoscopic myomectomy and morcellation. Fertil Steril. 2006; 85: 492-493.

13) Al-Talib A, Tulandi T.: Pathophysiology and possible iatrogenic cause of leiomyomatosis peritonealis disseminata. Gynecol Obstet Invest. 2010; 69: 239-244. 